\title{
Rainfall in Iberian transnational basins: a drier future for the Douro, Tagus and Guadiana?
}

\author{
Selma B. Guerreiro ${ }^{1}$ - Chris G. Kilsby ${ }^{1} \cdot$ Hayley J. Fowler ${ }^{1}$
}

Received: 17 December 2014 / Accepted: 29 November 2015 / Published online: 16 January 2016

C The Author(s) 2015. This article is published with open access at Springerlink.com

\begin{abstract}
Water scarcity is critical in both Portugal and Spain; therefore, assessing future changes in rainfall for this region is vital. We analyse rainfall projections from climate models in the CMIP5 ensemble for the transnational basins of the Douro, Tagus and Guadiana with the aim of estimating future impacts on water resources. Two downscaling methods (change factor and a variation of empirical quantile mapping) and two ways of analysing future rainfall changes (differences between 30 years periods and trends in transient rainfall) are used. For the 2050s, most models project a reduction in rainfall for all months and for both methods, but there is significant spread between models. Almost all significant seasonal trends identified from 1961 to 2100 are negative. For annual rainfall, only 3 (2) models show no significant trends for the Douro/Tagus (Guadiana), while the rest show negative trends up to $-6 \%$ per decade. Reductions in rainfall are projected for spring and autumn by almost all models, both downscaling methods and both ways of analysing changes. This increases the confidence in the projection of the lengthening of the dry season which could have serious impacts for agriculture, water supply and forest fires in the region. A considerable part of the climate model disagreement in the projection of future rainfall changes for the 2050s is shown to be due to the use of 30 year intervals, leading to the conclusion that such intervals are too short to be used under conditions of high inter-annual variability as found in the Iberian Peninsula.
\end{abstract}

\section{Introduction}

Water scarcity is critical in both Portugal and Spain due to the spatial and seasonal distribution of rainfall and its large interannual variability (Trigo and DaCamara 2000; Goodess and Jones 2002; Rodrigo and Trigo 2007; González-Hidalgo et al. 2010; Guerreiro et al. 2014). Therefore quantifying future changes in rainfall for this region is of vital importance. In this

Electronic supplementary material The online version of this article (doi:10.1007/s10584-015-1575-z) contains supplementary material, which is available to authorized users.

Selma B. Guerreiro

Selma.Guerreiro@newcastle.ac.uk 
paper we assess changes in rainfall projected by the latest generation of Atmosphere-Ocean General Circulation Models (GCMs) in the main international Iberian rivers (the Douro, the Tagus and the Guadiana).

Few studies exist concerning future rainfall in these basins; Kilsby et al. (2007) looked at the hydrological impacts of climate change on the Tagus and the Guadiana basins for 2070 2100 under the SRES A2 scenario. They used one RCM (HadRM3H driven by HadCM3) and two downscaling techniques: monthly bias correction and a circulation pattern (CP) based stochastic rainfall model. Year-round rainfall decreases were projected, with annual mean changes in rainfall for the Guadiana of $-30.5 \%$ (bias correction) and $-15.1 \%(\mathrm{CP})$ and for the Tagus -24.3 and $-11.5 \%$. Ekström et al. (2007) estimated the uncertainty of projections for the combined area of the Tagus and Guadiana basins using climate model results available from PRUDENCE (http://prudence.dmi.dk/). Annual precipitation changes between control (1961-1990) and future (2070-2099) were between $-42 \%$ and $+2 \%\left(1^{\text {st }}\right.$ and $99^{\text {th }}$ percentile). A seasonal analysis showed a wide range of projections for the winter (between $-19 \%$ and + $22 \%$ ) and decreases in rainfall for all models for other seasons: -62 to $-18 \%$ for MAM, -83 to $-2 \%$ for JJA and -46 to $-3 \%$ for SON (Hingray et al. 2007).

Looking at the wider region, both Portugal and Spain have performed national studies of climate change impacts (Santos et al. 2002; Brunet et al. 2009) based on GCMs from the third phase of the Climate Model Intercomparison Project (CMIP3). The studies use different methodologies for selection and downscaling the GCMs, but both found significant disagreement between models and a wide range of projections for rainfall.

Several studies have examined the Mediterranean area which includes the Iberian Peninsula, for example, Hertig and Jacobeit (2008). using statistical downscaling applied to seven GCM runs (SRES-A2 scenario), projected an increase in winter precipitation and a decrease in autumn and spring precipitation for the western and northern Mediterranean regions (2071-2100 compared to 1990-2019). Giorgi and Lionello (2008) analysed climate projections for the Mediterranean region using GCMs from CMIP3, RCMs from PRUDENCE and a $20 \mathrm{~km}$ resolution model. They found that climate projections from different model resolutions were broadly consistent, despite the higher resolution models showing orographicinduced rainfall patterns, which were absent in GCMs. The results showed a general drying and a pronounced warming, especially in summer, associated with a northward shift of the Atlantic storm-track. Inter-annual variability also increases, leading to periods of extreme heat and drought. They concluded that the changes were robust across time-periods and different emission scenarios; however, since multi-model means were analysed no assessment of the range of uncertainty was performed.

A new generation of GCMs are now available from CMIP5. Nevertheless, due to their coarse resolution, and inability to resolve significant sub-grid scale features, GCM outputs have to be downscaled to assess local/regional impacts of climate change (Fowler et al. 2007). Several downscaling techniques exist but they can be grouped into two main methods: dynamical and statistical.

Dynamical downscaling consists of embedding a regional climate model (RCM) or a limited-area model within a GCM (Fowler et al. 2007). RCMs show an improvement in the description of orographic effects, land-sea contrast, land surface characteristics and mesoscale circulation patterns (Maraun et al. 2010). However, they are extremely computationally intensive which limits the number of runs available and they inherit biases from the driving GCM (Fowler et al. 2007). RCMs also tend to show a wet (dry) bias in dry (wet) months and a warm bias in hot and dry regions (Maraun et al. 2010). Bias correction, based on empirical 
statistical relationships between model outputs and observations, has been used to transform the statistical properties of the modelled data (from an RCM or a GCM) to match the observed data. This assumes that this correction remains valid for future climate conditions (Boé et al. 2009).

Statistical downscaling is based on the establishment of empirical relationships between output variables from GCMs or RCMs and observed variables of the local climate. The simplest statistical downscaling method is the change-factor $(\mathrm{CF})$, perturbation or deltachange approach where the mean change between control and future GCM outputs is applied to observations. Its simplicity makes it possible to downscale several GCM/scenarios quickly but this method assumes that the GCM bias is constant in time and that variability and spatial patterns of climate will remain the same (Fowler et al. 2007). The CF method cannot be used to simulate transient changes in climate as the mean changes are calculated for specific time slices. Also, it can introduce a step change when applying different monthly change factors to the data. However it preserves spatial correlations between stations or grid points, which some complex statistical methods are not able to. The CF method is not suitable for the study of extreme events but might be appropriate for studies where changes in average values are relevant such as regional water resources studies (Sunyer et al. 2010).

Both statistical and dynamical downscaling methods inherit GCM circulation errors such as the insufficient number of blocking events over Europe which can cause drought and heat waves in the summer (Maraun et al. 2010). Therefore, it can be preferable to use a simple statistical method to downscale a large ensemble of GCMs in order to characterize the envelope of uncertainty than dynamically downscale a single or a few GCMs (Boé et al. 2009). In this study, simple downscaling methods were applied to the most recent ensemble of GCMs, CMIP5.

Questions remain on how to use downscaled outputs of multi-model ensembles in impact studies. Averaging across models is widely used but is hard to interpret and defend (Knutti et al. 2010a) and may produce physically implausible results (Knutti 2010). Choosing one, or only a small subset of climate models, based on similarity to observations for the variable of study is also very common, and was the methodology used in the Portuguese national study (Santos et al. 2002). However, producing similar conditions to those observed for a particular parameter, time interval or region does not mean that the relevant atmospheric physics are well simulated. Furthermore, since a general all-purpose metric to evaluate climate models has not been found and different metrics produce different rankings of models, excluding or weighting models might lead to overconfidence in projections and unjustified convergence (Knutti et al. 2010a). Another commonly used methodology is to build a probability density function (PDF) of change from the model ensemble. However, this assumes that models are independent, distributed around a "perfect model" and adequately sample the range of uncertainty (Knutti 2008). CMIP models are not independent, therefore model agreement might not be an indication of likelihood but a consequence of shared process representation and/or calibration on particular datasets (Knutti et al. 2010a). Also the sampling of models is not random or systematic (Knutti 2010).

On the other hand, choosing a few models representative of the range of climate model outputs from CMIP5 allows for assessment of the uncertainties associated with the projections and permits assessment of different adaptation strategies for different possible futures leading to robust adaptation. Nonetheless, one has to consider that extreme ends of the plausible range might not be sampled and that the chosen outcomes might be perceived as equally probable (Knutti et al. 2010b). 
In this paper, we present a range of GCM projections of rainfall for the Douro, the Tagus and the Guadiana. This is part of a wider study which analysed historical rainfall records (Guerreiro et al. 2014) as well as future drought and discharge for the three basins. Therefore the selection of climate models to analyse was made using both rainfall and temperature changes, despite only rainfall results being shown here. The paper is organized as follows. In section 2 we present the datasets used, followed by the methodology in section 3, including climate model selection and downscaling methods used. Section 4 presents the results and discussion (2050s projections and transient analysis) and the conclusions are presented in section 5. Additional tables and plots are presented in the Electronic Supplementary Material - ESM.

\section{Data}

A gridded daily rainfall dataset for Iberia - IB02 - was used. This was produced by merging two datasets, a Portuguese dataset: PT02 (Belo-Pereira et al. 2011) and a Spanish dataset: Spain02 (Herrera et al. 2012). Both datasets have a resolution of $0.2^{\circ} \times 0.2^{\circ}$ (see Fig. 1) and use ordinary kriging based on a dense network of quality-controlled gauges (2000 in Spain and 400 in Portugal). The IB02 dataset covers the period from 1950 to 2003.

Monthly rainfall outputs from CMIP5 models for RCP8.5 (1861-2100) were downloaded from http://climexp.knmi.nl where outputs are available regridded to a common grid $\left(2.5^{\circ}\right)$. Sanderson et al. (2011) showed that RCP8.5 is similar to SRES A1FI and, although these are the highest emission scenarios considered by IPCC, they still assume emissions well below what the current energy mix would produce in the future. Therefore the lower RCPs were not considered in this study.

At the time of download (June 2012) 65 model runs were available with the required variables (see Table 1 in the ESM). Four GCM grids were chosen (see Fig. 1) to cover as much of the basins as possible but without incorporating grids that contained ocean (since that could bias the values of the grid's spatial mean). 15 model runs were selected to assess future changes in mean monthly rainfall (see Table 2 of the ESM).

Fig. 1 Map of southwestern Europe with the grid points for IB02 (gridded observed rainfall data: grey) and the CMIP5 grid cells (red) used in this study. The three studied basins are also outlined in blue

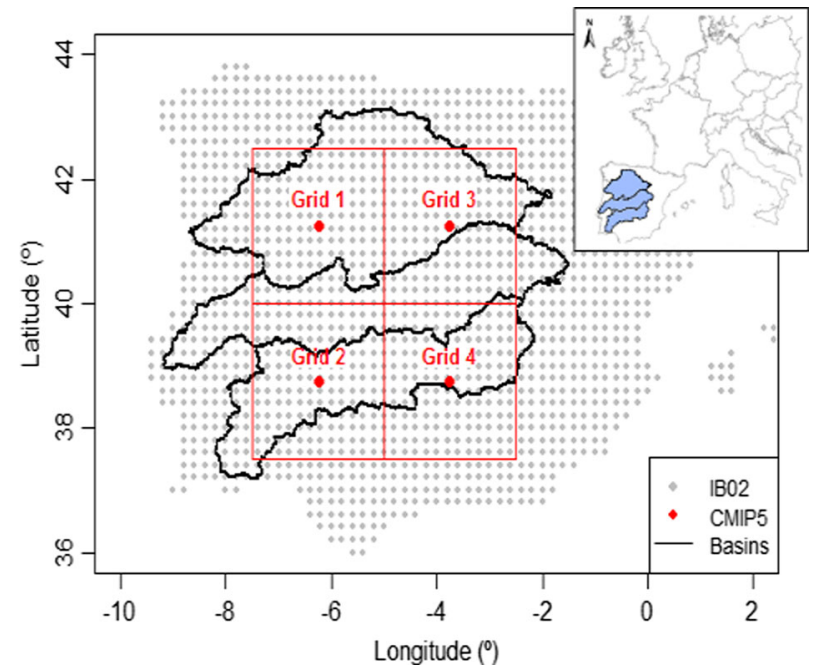




\section{Methodology}

\subsection{Climate model selection}

Although only rainfall is assessed here, the selection of climate models reflects the aims of the wider study focusing on future water resources in the Douro, Tagus and Guadiana basins. The study aimed to examine the range of possible futures projected by the latest generation of climate models (CMIP5). In view of the complexity of rainfall generation mechanisms in Iberia, and the CMIP5 models' systematic biases affecting the number and intensity of North Atlantic cyclones (Zappa et al. 2013) it is not realistic to expect a full physically coherent set of climate projections. Our approach here is to use a representative spread of projections to cover possible future conditions.

Since future drought and river discharge were also assessed in the wider study (which meant running a physically-based hydrological model) there was the need to select a subset of the 64 GCM runs available from CMIP5. The pragmatic decision was taken to select the smallest possible number of models that allowed the full uncertainty space for mean temperature and rainfall changes to be captured (across the four GCM grid cells and four seasons). Both rainfall and temperature changes were taken into account as temperature is then used to estimate potential evapotranspiration.

We analyse change for the 2041-2070 period (hereafter referred to as the 2050s) compared to the baseline period 1961-1990. The choice of future period to analyse is always subjective, but we considered the 2050 s as a relevant time-frame for water resources planning.

Since only two variables were of interest, the selection was made by plotting changes in mean temperature and rainfall for the four seasons and the four GCM grid cells (see Figure 1 of the ESM) and selecting model runs that covered the full uncertainty space (shown in Figure 2 of the ESM): this resulted in a selection of 15 model runs (Table 2 of the ESM). We did not attempt to represent the statistics of the CMIP5 ensemble but the full range of projected futures. By choosing enough models to cover the uncertainty space (available from CMIP5 model runs for RCP8.5) and by not assigning probabilities to any of the models, we hope to provide useful and transparent plausible future scenarios that can be used by others to test an array of adaptation alternatives, as suggested by Knutti et al. (2010b).

CMIP5 model performance in reproducing historical rainfall statistics was assessed by comparing the mean monthly rainfall and coefficient of variation (CV) between CMIP5 outputs and gridded observed rainfall (IB02) spatially aggregated to the CMIP5 grids for 1950-2003 (see Fig. 2 for plots of grids 1 and 2). In most cases the observed monthly mean lies within the range of the model mean monthly outputs. In the northern grid cells (1 and 3) most models are too wet throughout the year (except for September for grid cell 1), while in the southern grid cells (2 and 4) most models are too wet in summer. However, most models underestimate the $\mathrm{CV}$ of the observed data in all grid cells. These results point to the need for bias-correction of the model results before use in impact studies.

\subsection{Downscaling methods}

Due to the coarse resolution and the biases of GCMs, their outputs have to be downscaled before impact assessment. To assess uncertainties in downscaling we used two methods: change-factor and a variation of empirical quantile mapping. 
Mean and coefficient of variation of IB02 and CMIP5 (1950-2003)

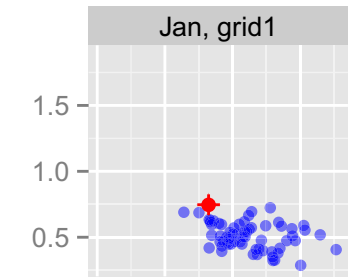
Jan, grid2

Feb, grid1

Feb, grid2
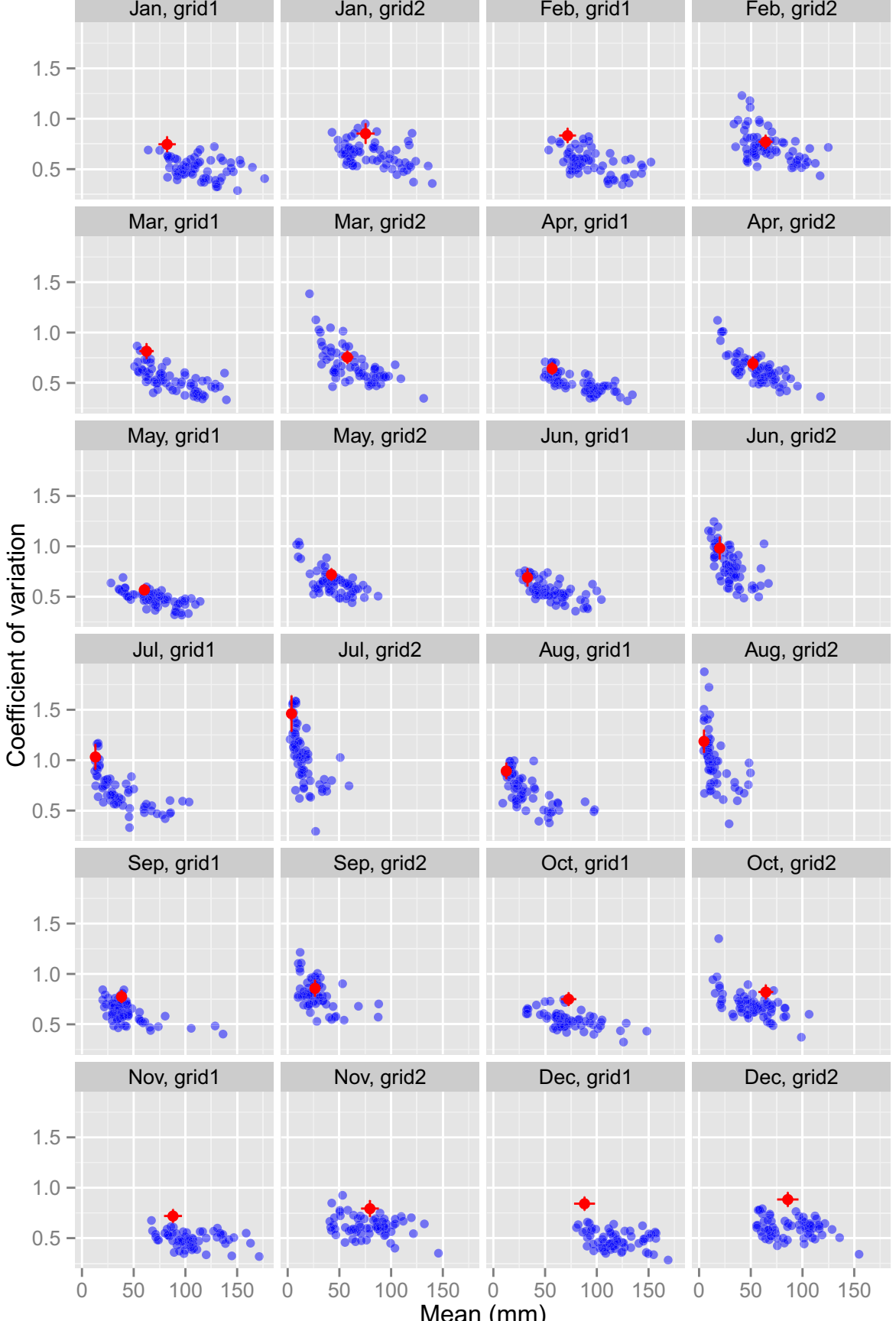

Dec, grid2

Mean $(\mathrm{mm})$

- CMIP5 - IB02

Fig. 2 Monthly rainfall means and coefficients of variation for spatially aggregated observations (IB02) in red and all CMIP5 model runs in blue for the period 1950 to 2003 (per month and per GCM grid cell). Error bars (using jackknife) of the observed rainfall are also plotted (although not always visible due to the scale of the plots) 


\subsubsection{Change factor approach $(C F)$}

For each month of the year and each GCM grid cell, a rainfall change factor was calculated by dividing the mean future rainfall (2041-2070) by the modelled mean historical rainfall (19611990). The change factors for each month and each GCM grid cell were then applied to the time series of observed rainfall inside that GCM grid cell for that month.

\subsubsection{Modified empirical quantile mapping (MEQM)}

Empirical cumulative distribution functions (ECDFs) were calculated for rainfall from each GCM grid cell and for IB02 (spatially aggregated to the GCM grid cell scale) for the 12 months for 1961-2003. Then for each GCM simulated rainfall output a corresponding observed value was found by matching the quantiles. For each month and each GCM, the quantile matching was used to identify the year of observed data (spatially aggregated monthly IB02) that had the same quantile as the GCM's year being downscaled for that month. Subsequently, the correspondent daily spatially distributed IB02 time-series for that year and that month was selected.

For example, let's imagine that for a specific January, the GCM simulated rainfall is $100 \mathrm{~mm}$. This corresponds to the quantile 0.674 using the ECDF calculated for the rainfall of that GCM. The quantile 0.674 corresponds to a rainfall value of $110 \mathrm{~mm}$ using the ECDF calculated for the historical rainfall (aggregated IB02). Subsequently, the daily spatially distributed January historical time-series whose aggregated value was $110 \mathrm{~mm}$ was selected.

To retain the spatial correlation of historical rainfall across basins, only one grid cell was used for the quantile matching. To capture the area that contributes most to the discharge of the basin, grid cell 1 was used for the Douro and the Tagus and grid cell 2 was used for the Guadiana

One of the shortcomings of quantile matching is that it can only produce events within the observed historical range. Therefore, rainfall during the future period with higher or lower values than the observed range was subsequently adjusted using a change factor approach. The largest number of future years outside the historical range is seen in the summer, with reductions in rainfall. Across all months, the mean number of years below the 1961-2003 range is 5.9\% for grid cell 1 and $5.5 \%$ for grid cell 2 . The number of years above the 1961-2003 range are all below $3 \%$ except for December for grid cell 1 which is $5 \%$ (see figure 4 in Supplementary information).

\section{Results and discussion}

\subsection{Projected changes in rainfall for the $2050 \mathrm{~s}$}

Figure 3 shows the relative changes (between 1961-1990 and 2041-2070) in monthly and annual rainfall for the Douro, the Tagus and the Guadiana basins for both downscaling methods and for the 15 GCMs. Due to high inter-annual variability of rainfall in this region, most changes are not statistically significant. In Table 1 we present the number of models showing significant changes for individual months between 1961-1990 and 2041-2070 using the Kolmogorov-Smirnov test at the 0.05 significance level. All significant changes are reductions in rainfall with the exception of one model in the Douro (model 4 for September) and one in the Tagus (model 14 for January).

Figure 3 shows that both downscaling methods produce similar rainfall projections for the 2050s, although the quantile mapping method tends to show larger inter-model dispersion which could perhaps be expected since more information is retained from the climate models. 


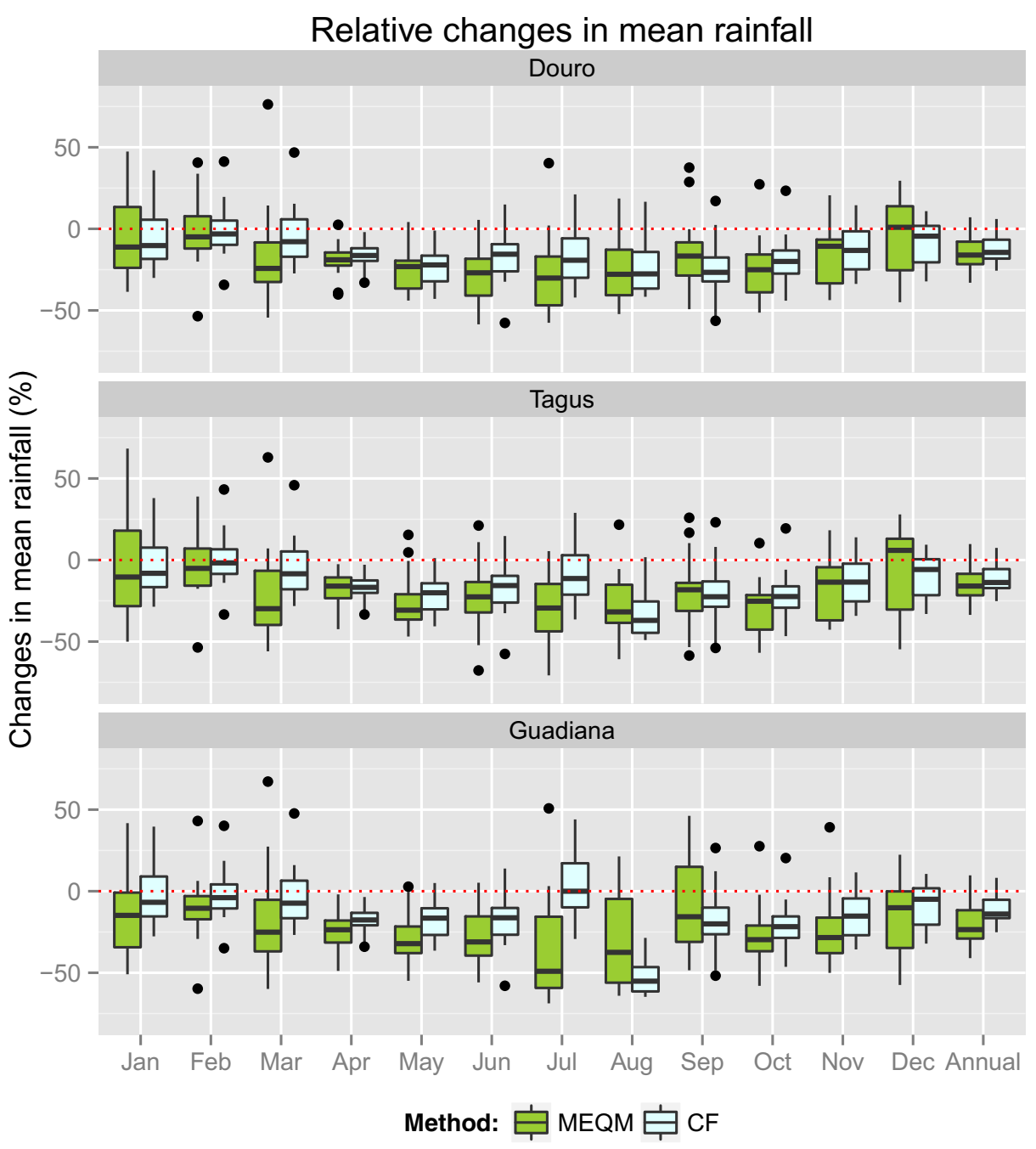

Fig. 3 Boxplots of relative changes in mean rainfall (between 1961-1990 and 2041-2070), per month (and annual), projected by 15 CMIP5 GCMs downscaled using change factor (CF) and the modified empirical quantile mapping (MEQM) methods for the Douro, Tagus and Guadiana basins. In each boxplot, the boxes show the interquartile range (IQR), the whiskers show the 1.5 IQR, the band inside shows the median and the dots show the outliers (points outside the 1.5 IQR)

The large differences in relative changes from the two methods in summer are, in reality, small differences in absolute terms but amplified by very low rainfall in these months (see Figure 5 in supplementary information for absolute changes).

Most models project a reduction in rainfall in all three basins and for both downscaling methods. However, inter-model dispersion on a monthly level is very large, with some models showing increases in rainfall. The projected change in annual rainfall ranges from $-33 \%$ to + $7 \%$ for the Douro, from $-34 \%$ to $+10 \%$ for the Tagus and from $-41 \%$ to $+10 \%$ for the Guadiana. Particularly relevant for future water resources management is the reduction in rainfall projected by almost all models, and both methods, for spring and autumn months. 
Table 1 Number of models showing significant changes in rainfall between 1961-1990 and 2050s using the KolmogorovSmirnov test at 0.05 significance level, per basin and per month (annual values also included) for the two downscaling methods (change factor and Modified Empirical Quantile Mapping - MEQM)

Note that all significant changes are reductions in rainfall

\begin{tabular}{|c|c|c|c|c|c|c|}
\hline \multirow[t]{2}{*}{ Month } & \multicolumn{2}{|l|}{ Douro } & \multicolumn{2}{|l|}{ Tagus } & \multicolumn{2}{|c|}{ Guadiana } \\
\hline & $\begin{array}{l}\text { Change } \\
\text { Factor }\end{array}$ & MEQM & $\begin{array}{l}\text { Change } \\
\text { Factor }\end{array}$ & MEQM & $\begin{array}{l}\text { Change } \\
\text { Factor }\end{array}$ & MEQM \\
\hline 1 & 0 & 2 & 0 & 4 & 0 & 2 \\
\hline 2 & 0 & 1 & 0 & 1 & 0 & 1 \\
\hline 3 & 0 & 4 & 0 & 5 & 0 & 3 \\
\hline 4 & 0 & 3 & 3 & 2 & 1 & 3 \\
\hline 5 & 4 & 4 & 4 & 5 & 0 & 8 \\
\hline 6 & 1 & 6 & 1 & 4 & 1 & 5 \\
\hline 7 & 0 & 5 & 0 & 4 & 0 & 4 \\
\hline 8 & 0 & 5 & 4 & 5 & 0 & 4 \\
\hline 9 & 0 & 4 & 1 & 3 & 0 & 1 \\
\hline 10 & 2 & 4 & 1 & 4 & 1 & 3 \\
\hline 11 & 0 & 3 & 1 & 3 & 0 & 2 \\
\hline 12 & 0 & 2 & 0 & 2 & 0 & 5 \\
\hline Annual & 0 & 2 & 0 & 2 & 0 & 5 \\
\hline
\end{tabular}

Projected monthly decreases are as large as $-54 \%$ for the Douro, $-56 \%$ for the Tagus and $-60 \%$ for the Guadiana in spring (MAM) and $-56 \%$ for the Douro and $-58 \%$ for both the Tagus and the Guadiana in autumn (SON).

Inter-model dispersion on a monthly level is large, with disagreement not only in the magnitude but also the sign of projected change (see Fig. 3). Since only one greenhouse gas scenario, RCP8.5, is used, this disagreement must result from either structural uncertainty in climate model response or from under-sampling arising from natural variability. Deser et al. (2012) showed that natural variability can contribute significantly to disagreement between different GCMs even for timescales of more than 50 years, and particularly for regions dominated by large-scale climate modes. Furthermore, Sokol Jurković and Pasarić (2013) showed that Iberia has high inter-annual rainfall variability, common in arid and semi-arid regions.

Assuming that climate models can reproduce natural climate variability, the robustness of using only 30-year time-slices to characterise climate for such regions should be examined. If 30 years is not long enough to characterize the local climate, than looking at differences between two 30-year periods will not be indicative of long term changes due to climate change (since the choice of 30-year period affects the results). We have assessed this robustness by analysing long records of observed rainfall for two representative long-record sites of these basins. Figure 4 demonstrates the variability in annual rainfall and how the choice of 30 -year period indeed can have a significant influence on the results. Therefore, we argue that a transient analysis using the entire available record of bias corrected rainfall (1961-2100) would be more informative since the effects of natural variability can then be separated from the climate change signal.

\subsection{Transient analysis}

To assess whether the disagreement between changes projected by different models can be explained by the selection of a specific 30 -year period in the context of natural variability, we examined long-term annual and seasonal trends for 1961-2100 using the empirical quantile 


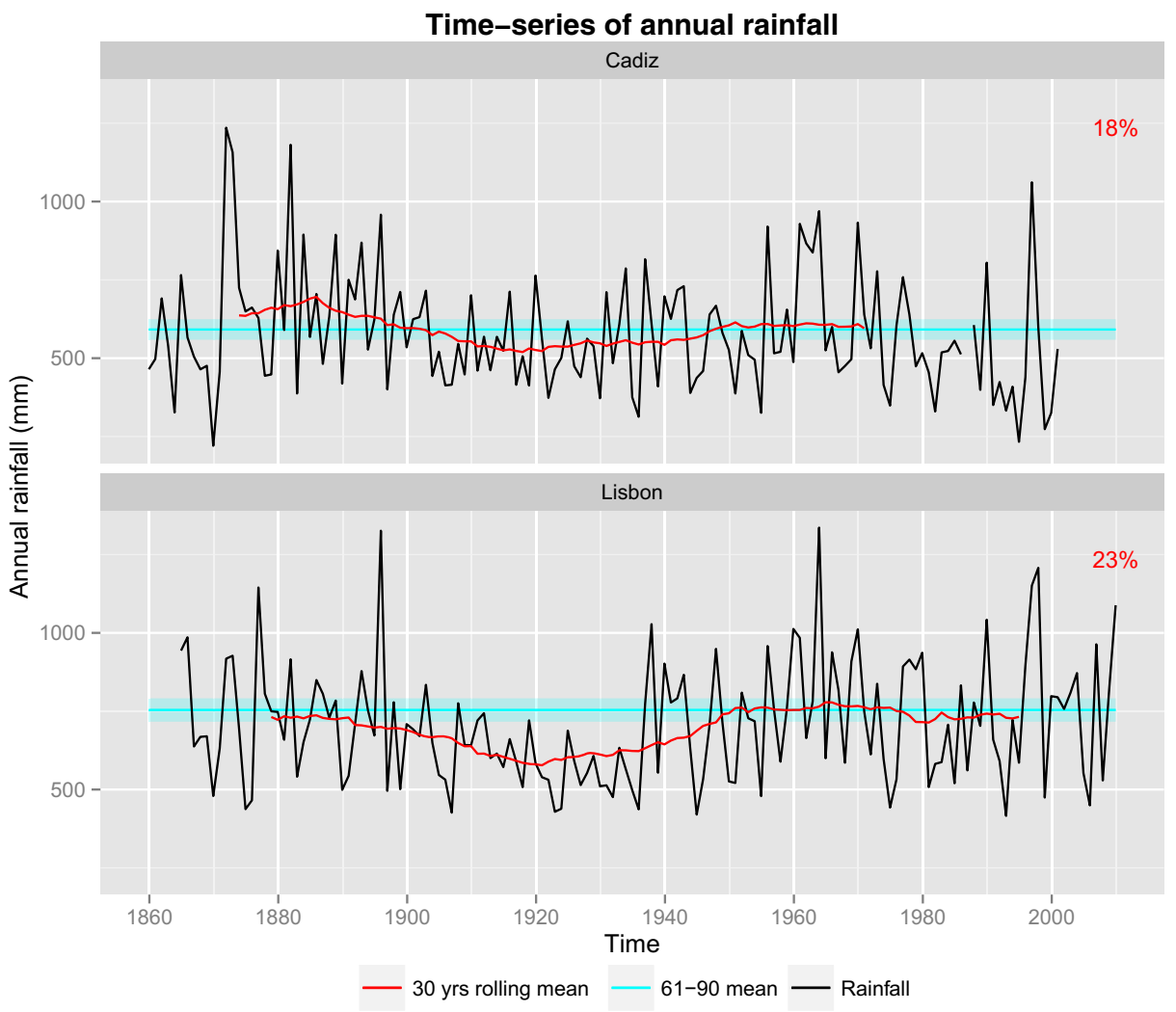

Fig. 4 Time-series of observed annual rainfall with 30-year rolling mean (red) and the 1961-1990 mean (with error band calculated using a jack-knife: cyan) for Cadiz (data from Gallego et al. (2011). and Lisbon (data from Stickler et al. (2014)). The maximum difference between the 1961-1990 mean and the 30-year rolling mean is presented in the top right corner of each plot as a percentage of the 1961-1990 mean

mapping outputs. As the CF method cannot produce transient outputs an inter-comparison of methods is not possible.

Trend significance was assessed using the Mann-Kendall test at the $5 \%$ level (Mann 1945; Kendall 1948) with pre-whitening as described in Yue et al. (2002). Trend magnitude was calculated using linear regression and presented in Table 2 as change per decade calculated as a percentage of the mean rainfall from 1961 to 2100. Results for annual rainfall for the Douro basin are shown in Fig. 5. Results for annual rainfall for the Tagus and Guadiana and for seasonal rainfall for all three basins are shown in Figures 6 to 19 of the ESM.

The results indicate a striking lack of positive trends in mean annual and seasonal rainfall in the Guadiana basin and the existence of only one (two) positive trends in the Tagus (Douro). This contrasts with the large range of both positive and negative model projections for mean rainfall when examining only change between the baseline and a 30 year time-slice for the 2050s, shown in section 3.1.

For annual rainfall, only 3 (2) models show no significant trends for the Douro/Tagus (Guadiana), the rest showed negative trends up to $-5 \%(-6 \%)$ for the Douro and the Tagus (Guadiana). Positive trends ( $2 \%$ or $3 \%$ per decade) are confined to the winter season (DJF) and to the Douro (2 models) and the Tagus (1 model). For winter rainfall a few models show 
Table 2 Magnitude of significant trends (at $5 \%$ level and assuming a linear trend) in total rainfall for each basin, each model, annually and for each season expressed as percentage of change per decade (relative to 1961-2100 mean)

\begin{tabular}{|c|c|c|c|c|c|c|c|c|c|c|c|c|c|c|c|c|}
\hline \multicolumn{2}{|l|}{ Models } & 1 & 2 & 3 & 4 & 5 & 6 & 7 & 8 & 9 & 10 & 11 & 12 & 13 & 14 & 15 \\
\hline \multirow{5}{*}{ Douro } & Annual & -4 & -3 & -2 & & -1 & -2 & -1 & -5 & -4 & & -4 & -2 & -4 & -3 & \\
\hline & SON & -5 & -4 & -5 & & -2 & -3 & -2 & -6 & -4 & -4 & -5 & -3 & -4 & -6 & \\
\hline & DJF & -3 & & & & & & & -4 & -2 & 3 & -4 & & & & 2 \\
\hline & MAM & -3 & -4 & -2 & -3 & -3 & -6 & -2 & -6 & -4 & -2 & -2 & -3 & -4 & -4 & \\
\hline & JJA & -4 & -3 & -7 & & & -4 & -5 & -6 & -5 & -4 & -7 & -5 & -9 & -7 & -4 \\
\hline \multirow{5}{*}{ Tagus } & Annual & -4 & -3 & -2 & & -2 & -2 & -1 & -5 & -3 & & -4 & -2 & -4 & -3 & \\
\hline & SON & -6 & -5 & -6 & & & -4 & -2 & -6 & -5 & -3 & -5 & -3 & -5 & -7 & \\
\hline & DJF & -4 & & & & & & & -4 & & 3 & -4 & & & & \\
\hline & MAM & -4 & -4 & -3 & -3 & -3 & -7 & -2 & -6 & -4 & -2 & -2 & -2 & -4 & -3 & \\
\hline & JJA & -4 & -4 & -8 & & & -4 & -5 & -4 & -6 & -5 & -6 & -5 & -9 & -6 & -4 \\
\hline \multirow{5}{*}{ Guadiana } & Annual & -5 & -3 & -3 & -1 & -2 & -2 & -1 & -6 & -5 & & -5 & -3 & -4 & -4 & \\
\hline & SON & -5 & -4 & -7 & & -2 & -4 & & -7 & -5 & -3 & -7 & -3 & -4 & -7 & \\
\hline & DJF & -5 & & & & & & & -6 & -5 & & -6 & & -4 & & \\
\hline & MAM & -4 & -5 & -3 & -3 & -3 & -7 & -3 & -6 & -5 & -3 & -2 & -3 & -3 & -4 & \\
\hline & JJA & -5 & -5 & -10 & & -3 & -5 & -4 & -5 & -3 & -5 & -6 & -7 & -9 & -10 & -4 \\
\hline
\end{tabular}

significant negative trends, especially in the Guadiana (up to $-4 \%$ per decade in the Douro and the Tagus and up to $-6 \%$ per decade in the Guadiana) but most show no significant trend.

In spring (MAM) and autumn (SON), most models show negative trends that reach $-6 \%$ per decade in the Douro and $-7 \%$ per decade in the Tagus and the Guadiana. This reinforces the possible problem of dry season lengthening identified in section 3.1. The largest relative changes are projected for summer (JJA) in all basins but these changes are small in absolute terms.

It is important to keep in mind that these are mean values of change per decade, associated with the calculation of long term linear trends; they do not imply a steady transition, and are themselves affected by the start and end point of the time series and the associated point in the natural cycles.

\section{Conclusions}

This study aims to provide useful and plausible future rainfall scenarios which can be subsequently used to test adaptation options for water resource management. For that purpose, we selected sufficient output from climate models to allow the full uncertainty range of projected changes in mean temperature and mean rainfall from CMIP5 (RCP8.5) to be studied.

Considerable spread was found within the projected changes for mean annual rainfall (range between $+10 \%$ and $-40 \%$ ), in agreement with both Portuguese and Spanish national climate change impact studies (Santos et al. 2002; Brunet et al. 2009) and the study by Ekström et al. (2007) for the Tagus and Guadiana.

Almost all models projected rainfall decreases in spring and autumn for both downscaling methods (CF and MEQM) that, in the most severe projections, meant a halving of the rainfall in these months. The projected ranges are similar to those obtained using a previous generation 


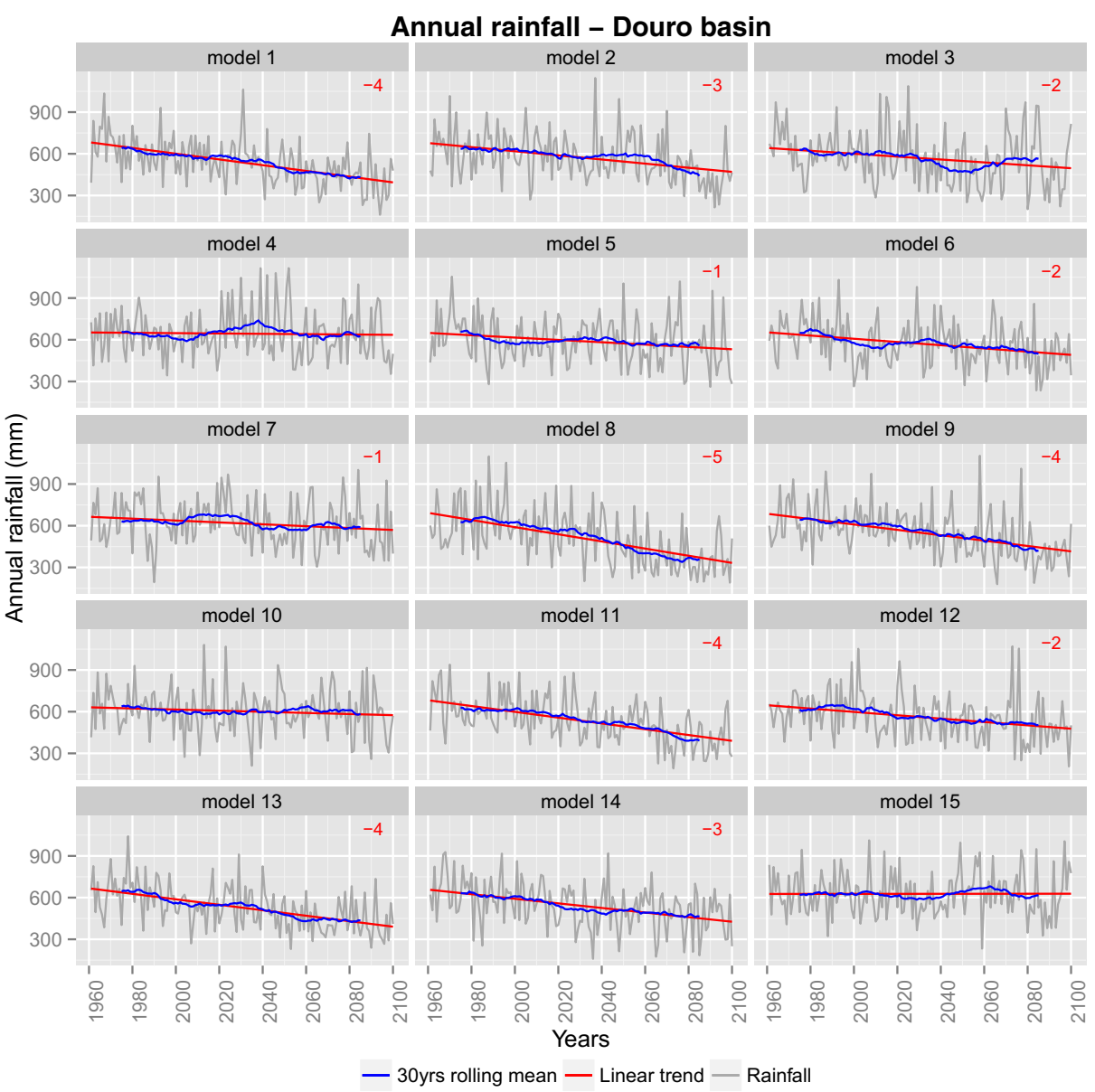

Fig. 5 Annual transient quantile-mapped rainfall for the 15 GCMs in the Douro basin. 30-year rolling means are plotted in purple and linear trends in red. The magnitude of monotonic linear trends significant at the $5 \%$ level (using the Mann-Kendall test) are presented in the upper right corner of the plot in percentage of change per decade (relative to 1961-2100 mean)

of climate models (Ekström et al. 2007; Hingray et al. 2007) for the Tagus and Guadiana for the $2080 \mathrm{~s}$.

In addition to assessing changes on 30 year time-slices, transient changes from 1961 to 2100 were investigated. The magnitude of long-term linear trends was calculated for annual and seasonal quantile-mapped rainfall for each basin. No significant positive trends were projected in annual rainfall or in any season other than winter in the Douro (two models) and the Tagus (one model). In spring (MAM) and autumn (SON) the majority of models projected negative trends that reached $-6 \%$ per decade in the Douro and $-7 \%$ per decade in the Tagus and the Guadiana. For annual rainfall, only 3 (2) models show no significant trends for the Douro/Tagus (Guadiana), the rest showed negative trends up to $-5 \%(-6 \%)$ for the Douro and the Tagus (Guadiana).

Consistent reductions in rainfall were projected for spring and autumn by almost all models, both downscaling methods and both methods of analysing future rainfall changes (time-slice and trend 
analysis). This agreement increases the confidence in the projection of a lengthening of the dry season in the three basins with serious implications for agriculture, water supply and forest fires.

An important qualification to the likely magnitude of these future changes is revealed by our comparative analysis using both transients (1961-2100) and limited time-slices (30 year periods). We have shown that assessing rainfall changes using 30 year time-slices results in unacceptably large uncertainties. In regimes with large natural, interannual variability, we show that 30 years is insufficient to characterize the climate due to the large natural multidecadal variability which cannot be distinguished from climate change. On the other hand, the use of longer time-series may make it possible to separate the climate change signal from natural variability. We recommend, therefore, that more attention is given to using ensembles of longer period transient climate model simulations rather than fixed time-slices. As well as enabling the identification of the climate change signal from the natural variability, a further benefit is that the natural variability can be better quantified and used together with the climate change signal to inform robust adaptation.

\begin{abstract}
Acknowledgments This work was financed by FCT, the Portuguese Foundation for Science and Technology (grant SFRH/BD/69070/2010). Prof Hayley Fowler is funded by the Wolfson Foundation and the Royal Society as a Royal Society Wolfson Research Merit Award holder. We acknowledge the World Climate Research Programme's Working Group on Coupled Modelling, which is responsible for CMIP, and thank the climate modelling groups for producing and making available their model output. We would also like to thank Dr Geert Jan van Oldenborgh from the KNMI Climate Explorer website for making outputs from CMIP5 available in an easy to use and downloadable format.
\end{abstract}

Open Access This article is distributed under the terms of the Creative Commons Attribution 4.0 International License (http://creativecommons.org/licenses/by/4.0/), which permits unrestricted use, distribution, and reproduction in any medium, provided you give appropriate credit to the original author(s) and the source, provide a link to the Creative Commons license, and indicate if changes were made.

\title{
References
}

Belo-Pereira M, Dutra E, Viterbo P (2011) Evaluation of global precipitation data sets over the Iberian Peninsula. J Geophys Res 116(D20101), 16

Boé J, Terray L, Martin E, Habets F (2009) Projected changes in components of the hydrological cycle in French river basins during the 21st century. Water Resour Res 45. doi: 10.1029/2008WR007437

Brunet M, Casado MJ, Castro Md, Galán P, López JA, Martín JM, Pastor A, Petisco E, Ramos P, Ribalaygua J, Rodríguez E, Sanz I, Torres L (2009) Generación de Escenarios Regionalizados de Cambio Climático para España.Agencia Estatal de Meteorología, Ministerio de Agricultura Alimentación y Medio Ambiente. [Online]. Available at: http://www.aemet.es/en/elclima/cambio_climat/escenarios

Deser C, Phillips A, Bourdette V, Teng H (2012) Uncertainty in climate change projections: the role of internal variability. Clim Dyn 38(3-4):527-546

Ekström M, Hingray B, Mezghani A, Jones PD (2007) Regional climate model data used within the SWURVE project 2: addressing uncertainty in regional climate model data for five European case study areas. Hydrol Earth Syst Sci 11(3):1085-1096

Fowler HJ, Blenkinsop S, Tebaldi C (2007) Linking climate change modelling to impacts studies: recent advances in downscaling techniques for hydrological modelling. Int J Climatol 27:1547-1578

Gallego MC, Trigo RM, Vaquero JM, Brunet M, García JA, Sigró J, Valente MA (2011) Trends in frequency indices of daily precipitation over the Iberian Peninsula during the last century. J Geophys Res: Atmos 116(2). doi: 10.1029/2010JD014255

Giorgi F, Lionello P (2008) Climate change projections for the Mediterranean region. Glob Planet Chang 63(2-3): 90-104

González-Hidalgo JC, Brunetti M, Luis M (2010) A new tool for monthly precipitation analysis in Spain: MOPREDAS database (monthly precipitation trends December 1945-November 2005). Int J Climatol 31(5):715-731. doi:10.1002/joc.2115 
Goodess CM, Jones PD (2002) Links between circulation and changes in the characteristics of Iberian rainfall. Int J Climatol 22(13):1593-1615

Guerreiro SB, Kilsby CG, Serinaldi F (2014) Analysis of time variation of rainfall in transnational basins in Iberia: abrupt changes or trends? Int J Climatol 34(1):114-133

Herrera S, Gutiérrez JM, Ancell R, Pons MR, Frías MD, Fernández J (2012) Development and analysis of a 50year high-resolution daily gridded precipitation dataset over Spain (Spain02). Int J Climatol 32:74-85

Hertig E, Jacobeit J (2008) Assessments of Mediterranean precipitation changes for the 21 st century using statistical downscaling techniques. Int J Climatol 28(8):1025-1045

Hingray B, Mezghani A, Buishand TA (2007) Development of probability distributions for regional climate change from uncertain global mean warming and an uncertain scaling relationship. Hydrol Earth Syst Sci 11(3):1097-1114

Kendall MG (1948) Rank correlation methods. Griffin, Oxford

Kilsby CG, Tellier SS, Fowler HJ, Howels TR (2007) Hydrological impacts of climate change on the Tejo and Guadiana Rivers. Hydrol Earth Syst Sci 11(3):1175-1189

Knutti R (2008) Should we believe model predictions of future climate change? Philos Trans R Soc A Math Phys Eng Sci 366(1885):4647-4664

Knutti R (2010) The end of model democracy? Clim Chang 102(3):395-404

Knutti R, Abramowitz G, Collins M, Eyring V, Gleckler PJ, Hewitson B, Mearns L (2010a) Good practice guidance paper on assessing and combining multi model climate projections. In: Stocker TF, Qin D, Plattner G-K, Tignor M, Midgley PM (eds) Meeting report of the intergovernmental panel on climate change expert meeting on assessing and combining multi model climate projections. IPCC Working Group I Technical Support Unit, University of Bern, Bern, Switzerland. In: Meeting Report of the Intergovernmental Panel on Climate Change Expert Meeting on Assessing and Combining Multi Model Climate Projections

Knutti R, Furrer R, Tebaldi C, Cermak J, Meehl GA (2010b) Challenges in combining projections from multiple climate models. J Clim 23(10):2739-2758

Mann HB (1945) Nonparametric tests against trend. Econometria 13(3):245-259

Maraun D, Wetterhall F, Ireson AM, Chandler RE, Kendon EJ, Widmann M, Brienen S, Rust HW, Sauter T, Themel M, Venema VKC, Chun KP, Goodess CM, Jones RG, Onof C, Vrac M, Thiele-Eich I (2010) Precipitation downscaling under climate change: recent developments to bridge the gap between dynamical models and the end user. Rev Geophys 48(3)

Rodrigo FS, Trigo RM (2007) Trends in daily rainfall in the Iberian Peninsula from 1951 to 2002. Int J Climatol 27:513-529

Sanderson BM, O’Neill BC, Kiehl JT, Meehl GA, Knutti R, Washington WM (2011) The response of the climate system to very high greenhouse gas emission scenarios. Environ Res Lett 6(3):11

Santos FD, Forbes K, Moita R (2002) Climate Change in Portugal. Scenarios, Impacts and Adaptation Measures - SIAM Project. Lisbon, Portugal: Gradiva

Sokol Jurković R, Pasarić Z (2013) Spatial variability of annual precipitation using globally gridded data sets from 1951 to 2000. Int J Climatol 33(3):690-698

Stickler A, Brönnimann S, Valente MA, Bethke J, Sterin A, Jourdain S, Roucaute E, Vasquez MV, Reyes DA, Allan R, Dee D (2014) ERA-CLIM: historical surface and upper-air data for future reanalyses. Bull Am Meteorol Soc 95(9):1419-1430

Sunyer MA, Madsen H, Ang PH (2010) A comparison of different regional climate models and statistical downscaling methods for extreme rainfall estimation under climate change. Atmos Res 103:119-128

Trigo RM, DaCamara CC (2000) Circulation weather types and their influence on the precipitation regime in Portugal. Int J Climatol 20:1559-1581

Yue S, Pilon P, Phinney B, Cavadias G (2002) The influence of autocorrelation on the ability to detect trend in hydrological series. Hydrol Process 16(9):1807-1829

Zappa G, Shaffrey LC, Hodges KI (2013) The ability of CMIP5 models to simulate North Atlantic extratropical cyclones. J Clim 26(15):5379-5396 